\title{
Assessment Of The Estonian Labor Market Development
}

Kaie Kerem, (Email: kkerem@tv.ttu.ee), Tallinn University of Technology, Estonia Mare Randveer, (Email: mare@tv.ttu.ee),Tallinn University of Technology, Estonia

\begin{abstract}
Today' $s$ world is characterized by globalization and rapid technological change. Successful development of the European Union 's economic system requires reforming labor market and social policies both at EU and national levels. The goal of these reforms has to be improving EU 's economic performance and guaranteeing better social protection. It can be agreed that each national government has to devise and implement its own strategy for reforming national labor market and social policies. One of extremely important problems is market flexibility - especially labor market flexibility. Only flexible markets allow the necessary transfer of resources across firms, sectors or regions. The Estonian labor market is quite flexible and it is characterized by a weak role of trade unions and modest regulation by the government. The objective of the paper is to review and analyze labor market developments in Estonia; to examine trends in aggregate employment and unemployment and to find appropriate employment policy responses in order to increase labor market flexibility. The paper will rely on the analysis of statistical data and labor force survey data over the period 1990-2006.
\end{abstract}

\section{Introduction}

atisfactory growth performance of any European Union member state depends greatly on market flexibility - especially labor market flexibility. The labor market rigidities (both exogenous and endogenous) impede effective participation in the global economy, as well as more sustainable growth of output and employment. Only flexible markets allow the necessary transfer of resources across firms, sectors or regions.

Market flexibility is even more important for members of the European economic and monetary union. The members of the eurozone sharing a common monetary policy cannot use the exchange rate as an instrument of flexibility. Thus, one of the possible adjustment mechanisms to asymmetric shocks is labor market flexibility as a shock absorber. Making labor markets in EU member states more flexible to inject new competition into product markets is not an easy process. On the contrary, it requires painful changes (The Economist, vol. 382, No. 8520, p. $11)$.

The consequences of government interventions in the labor market have to be studied carefully as free labor markets are imperfect and nearly every state tries therefore to protect the employees from employers. Governments fight against discrimination in the labor market by determining for example the minimum wage. They regulate employment relations; empower labor unions to represent workers collectively and provide social insurance against unemployment, old age, disability, sickness and health, or death as Botero et al (2004) argue.

These researchers have studied some of the theories of the government intervention in the labor market, for instance efficiency theories that contend that regulations are necessary to combat market failure. Their conclusion is that heavier regulation of labor has adverse consequences for labor force participation and unemployment, especially of the young. Siebert states that efficiency arguments for strict labor regulation are questionable because of unemployment effects. He agrees that for outsider groups - the young, the old and the inexperienced - job opportunities will be reduced by such regulation. Strict labor regulation also drives up long-term unemployment (Siebert, 2006). Recent researches show also that in more deregulated labor markets which also have a lower presence of trade unions, the response of real wages to unemployment is much larger (Clar et al (2007). 
In order to avoid the situation where the employers' decisions that base on the short-term market fluctuations hinder the quality of the labor force in a long run, the flexicurity approach can be used. The Estonian Action Plan (2005) envisages, following the flexicurity approach, that the well-being of workers and flexible labor relations will be combined through balancing relatively liberal labor market legislation with sufficient guarantees during the period of unemployment.

There are a large number of definitions of labor market flexibility in economic literature (See Paas et al, 2002 and Eamets and Masso, 2003 for overviews). Usually the labor market is considered the more flexible, the more decentralized is the wage setting process, the lower the lay-off protection, the lower the unemployment benefits, the more open the social dialogue and the less directly intervening the active labor market policy (Freytag, 2002).

Analysis of Estonian labor market flexibility has mostly concentrated on the following aspects of flexibility: institutional factors and transitions between different labor market states (Eamets and Masso, 2003; Freytag, 2002; Rõõm, 2002; Toomet, 2000 and 2001; Cazes and Nesperova, 2001; Eamets, 2001 Haltiwanger and Vodopivec, 1999).

From an institutional point of view Estonian labor market policy has been mainly characterized by low unemployment benefits - clearly too low for any long-term reliance to be put on them. However, the low level of benefits has made the cost of the program to the government less expensive. The low level of benefits was one of the reasons why many of the unemployed did not register themselves at employment offices. In 2001 the unemployment insurance tax was introduced. Its aim is to reduce some social risks and it is divided between the employee and the employer.

The results of the analysis of the second aspect of labor market flexibility - labor mobility in terms of movements between labor market statuses (employment, unemployment and non-participation), and between sectors of economy and regions - indicate that in Estonia labor mobility was higher than in other transition countries (with the exception of the Czech Republic), especially at the beginning of the transition period (Faggio and Koenings, 1999; Haltiwanger and Vodopivec, 1999; Eamets and Masso, 2003). As regards the set of relevant labor market institutions we focus in our report on unemployment benefits, unionization of labor market and active labor market policies.

This paper reviews and analyses labor market developments in Estonia. Section 2 gives an overview of the Estonian labor market. In section 3, labor market unionization is discussed, with a particular focus on wage bargaining models. In section 4, labor market policy measures and their use in Estonia are examined. Section 5 presents the conclusions.

In the analysis below we use data on the employment and unemployment in the EU member states taken from the following Internet sources: International Labour Office (Laborsta Internet) and Eurostat. In our research we also used data on the labor market trends published by OECD and the Statistical Office of Estonia over the years 1991-2006.

\section{Main Characteristics Of The Estonian Labor Market}

During the last 15 years there has been a noteworthy decrease in employment in Estonia. In 1990-2005 the employment rate has declined by about 10 percentage points (in 1990 the employment rate was 77.4 per cent, in 2005, 64.4 per cent). The employment rate in Estonia is approximately 1 percentage point lower than the EU-15 average (65.2 per cent in 2005) and approximately about the same amount higher than in EU-25 and EU-27 (respectively 63.8 and 63.4 per cent). Estonian employment rate is higher than that of Latvia and Lithuania. Latvian employment rate is close to EU-25 and Lithuanian employment rate is approximately 1 percentage point lower than that of EU-25 (see Figure 1). 
According to Eurostat, about 64 per cent of the EU-25's population aged between 15 and 64 were employed in 2005. In Denmark, Ireland, Cyprus, the Netherlands, Finland, Sweden and the United Kingdom the employment rate was at or above 67 per cent. At the same time the employment rate in Italy, Hungary, Malta, Poland and Slovakia was below 60 per cent.

Figure 1: Employment rate in \% in 1998-2005

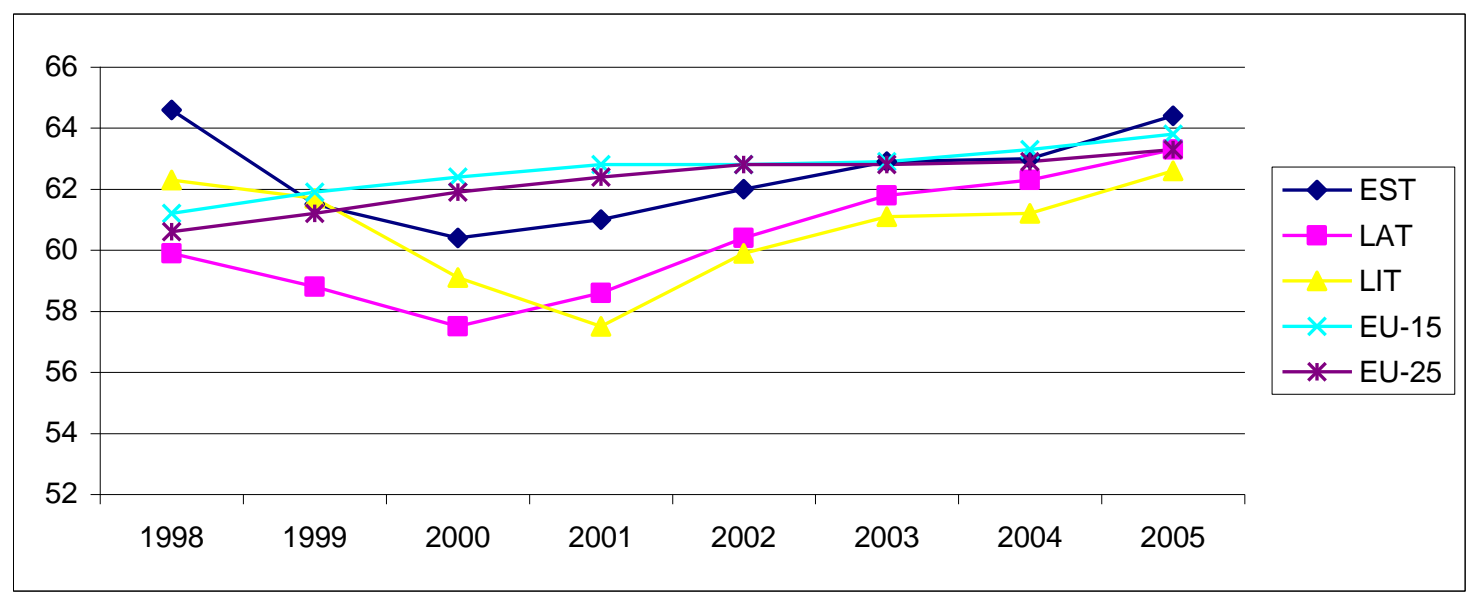

The EU-25 employment rate for women (56 per cent) stood considerably lower than for men (71 per cent). At the same time, comparison of the employment rate of Estonian men with that of EU-25 shows that it is one of the lowest in EU-25. In 2005 the men's employment rate in Estonia was 67 per cent. Men's employment rate was lower than in Estonia only in Lithuania (66.1 per cent) and Poland (58.9 per cent). At the same time the employment rate of women in Estonia (62.1 per cent) is about 6 percentage points higher than in EU-25 average. Women's employment was higher than in Estonia in five member states: the United Kingdom (77.6 per cent), Denmark (71.9 per cent), Sweden (70.4 per cent), the Netherlands (66.5 per cent), and Finland (66.5 per cent).

As to the branches of the Estonian economy, Estonia has been able to maintain employment in manufacturing: in 2005 the employment in manufacturing was almost the same as in 1991 (approximately 35 per cent). Moreover, Estonia has managed to drastically reduce agricultural employment. The share of employees in agriculture fell from over 20 per cent in 1991 to less than 5 per cent in 2005. One reason for some of these changes could be heritage from the Soviet economic system. The structure of the Estonian economy then did not satisfy the local needs but was part of the quite absurd division of labor of the large empire. Therefore, after Estonia regained its independence employment declined primarily in agriculture, fishery and mining, and increased in state administration, financial intermediation and trade. The labor force that became redundant during the rapid restructuring of the economy, attempted to find work in the new quickly developing areas of the economy like commerce, hotel business etc. In this new situation, a significant part of the labor force has had to acquire new qualifications. Technological changes, accompanied by the decline in labor intensity, have exerted influence on employment in transport and communications, etc. Such changes in sectoral employment have taken 15-20 years in most of the developed countries. In Estonia they happened 2 or 3 times faster. If we consider the relatively narrow export basis of Estonia, where timber and sub-contracts are dominating, the economic structure and thus the employment are expected to adjust further.

According to the Eurostat, the unemployment rate in the EU-25 members states in 2006 was 7.9 per cent, ranging from 14 per cent in Poland and 13.3 per cent in Slovakia down to less than 5.5 per cent in Denmark, Ireland, Cyprus, Luxembourg, the Netherlands, Austria and the United Kingdom. The Estonian unemployment rate was 5.6 per cent in 2006. 
Estonian labor market developments have been unlike those of other Central and Eastern European countries. This means relatively low unemployment rate at the beginning of the transition period and a rapid change in labor reallocation. In 1991, the first instances of unemployment were registered. In 1999 the unemployment rate was for the first time higher than 10 per cent. As a result of the Russian financial crisis (1998-1999) and the loss of the Russian market, the unemployment rate rose sharply in 2000 reaching the record high -12.8 per cent. Analogous trends can be observed in Latvia as well as Lithuania In Latvia the unemployment rate was the highest in 1998 (14.3 per cent) and in Lithuania in 2001 (16.5 per cent) (see Figure 2).

Figure 2: Unemployment rate in \% in 1998-2006

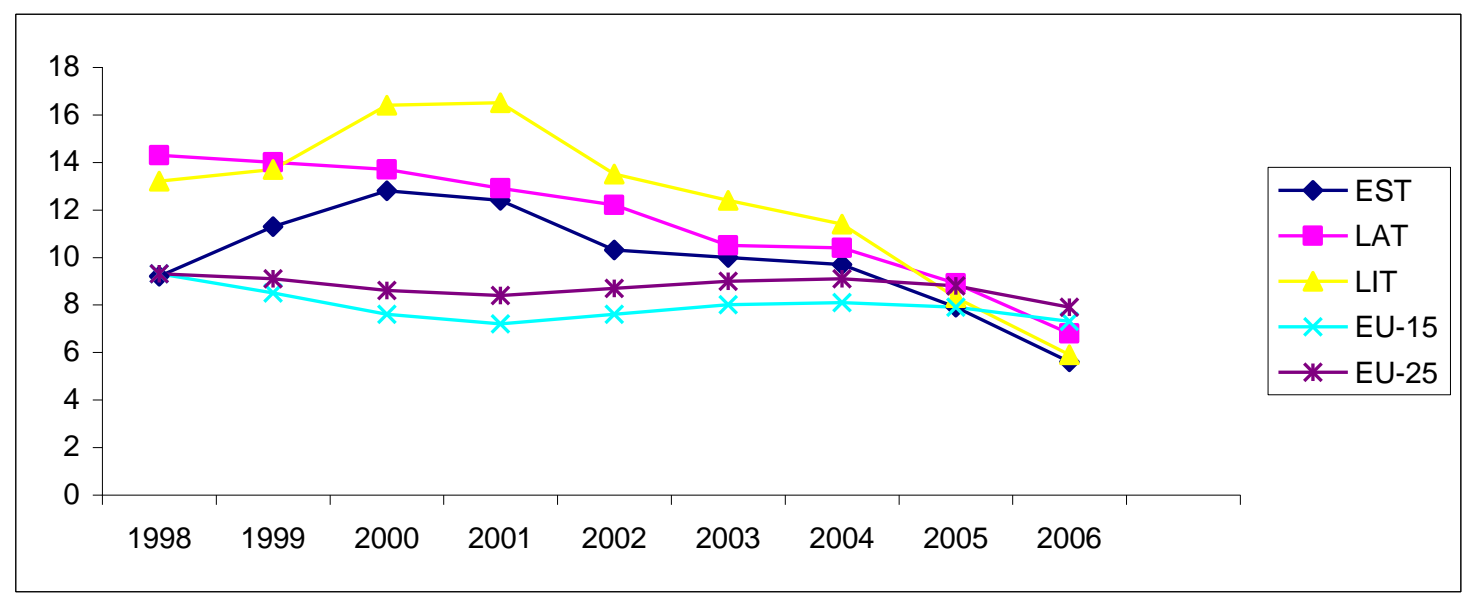

The unemployment rate for women $(8.9 \%)$ in the EU-25 in 2006 was higher than that for men (7.0 per cent). This pattern was reflected in the majority of member states, except in Estonia, Latvia, Lithuania (see Figure 3) and also in Ireland and the United Kingdom. Since 1995 men in Estonia have had a higher unemployment rate compared to women. The same trend is true also about Latvia and Lithuania. Unemployment rate is especially high also among less educated persons. A large number of the registered unemployed (28 per cent) only have basic education or less. One of the reasons for the higher unemployment rate of men compared to women in Estonia is men's lower educational level.

Figure 3: Unemployment rate of females and males in 2006

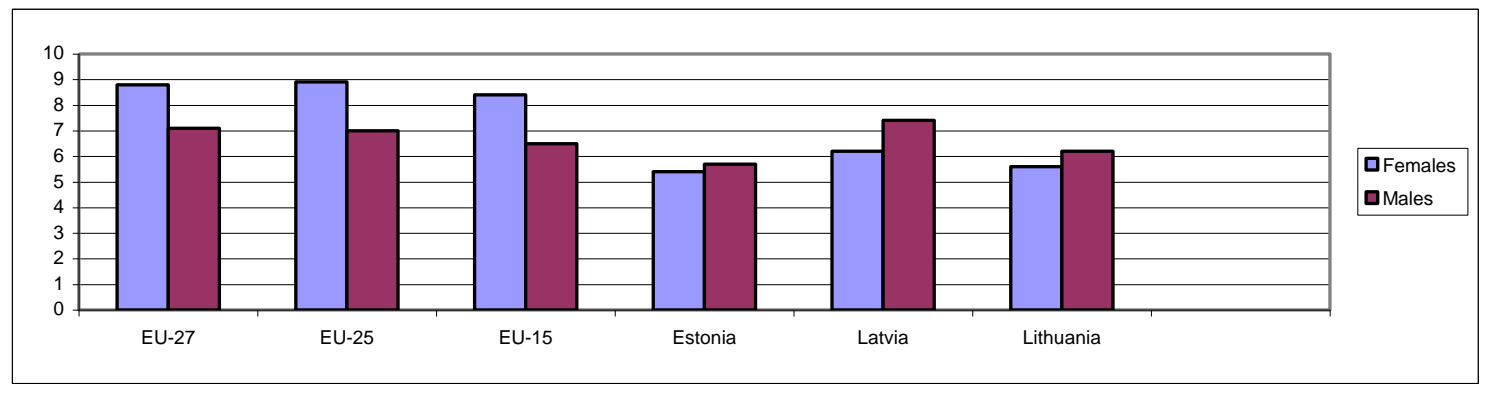

The main risk groups in the Estonian labor market are the young and the long-term unemployed. The unemployment rate is highest among the young workers aged 15-24: in 2005 they formed 15.9 per cent still it is lower than the EU-25 average (18.5 per cent). 
The ratio of the long-term unemployed provides one measure of labor market flexibility (Europe in Figures, 2007). Long-term unemployed (persons in the labor force or among the unemployed persons, who have been without work for a long time, i.e. have been seeking employment for 12 months or more) form a significant part of all unemployed persons in Estonia. The long-term unemployment rate in Estonia (4.2 per cent) is close to that in Latvia and Lithuania. The EU-25 average long-term unemployment rate was 3.9 per cent in 2005 . Analyzing the risk factors hindering reintegration into the labor market the researchers have found that people with a low educational level and elderly workers have a higher risk of becoming long-term unemployed (Venesaar et al 2001).

In Estonia a very serious problem is structural unemployment. It means that the skills and qualifications of the employees do not correspond to the demands of the labor market. Structural unemployment has been mentioned as the main reason for long-term unemployment in Estonia. It means that those people who have been released from enterprises mainly because of lay-offs are very often not ready to acquire modern skills and to adjust to the changes in the labor market and therefore are likely to become long-term unemployed.

The aging population and relatively high unemployment rate in the EU have induced the Union to address problems of employment and unemployment increasingly more seriously. On 12 April 2005, the European Commission released an integrated set of guidelines for growth and jobs, covering recommendations on broad economy policy and proposals on employment guidelines for the period 2005-2008 (Europe in Figures, 2007). The respective guidelines have been worked out also in Estonia (Action Plan, 2005).

\section{Unionization Of Labor Market}

Influence of unionization on the flexibility of labor and wages is addressed directly in the wage bargaining models. They predict that wages may be set above the market clearing rate due to the labor market imperfections, which impose fairness considerations on firms. In principle, it is possible to distinguish three levels of bargaining. In the case of a national, i.e. completely centralized bargaining, the wage differentials reflect the negotiating power and preferences of the central labor market organizations. In the case of a sectoral or industry level bargaining the degree of centralization is smaller and the wage differentials are greater.

Finally, at an enterprise or completely decentralized level of bargaining wages are set within the firms and therefore wage differentials are infinite. The bargaining levels can also be considered in a context of wage flexibility and adjustment capacity of the labor market. The most long-term and redistributive agreements are made at national level, whereas in the case of enterprise level bargaining companies adjust wages depending on the size and direction of the exogenous shocks.

Bargaining models ultimately lead to a loss of efficiency due to distortions that trade unions cause to firms' labor demand decisions. Sectoral or occupational labor unions represent a monopoly on the labor market thus having a power to set the wage higher than a competitive level. This can have two possible outcomes on national wages and employment depending on the degree and importance of union coverage. First, the overall employment may be reduced as firms demand less workers if wages are high. Second, firms may just lay off some unionized workers, inducing a potential increase in the supply of non-unionized labor whose wages will then fall. Taking into account these possible lay-offs, a standard unions' trade-off would be higher wages vs. higher employment.

The bargaining coordination across firms and sectors in Estonia is weak. Estonia has a tripartite negotiating body at the national level. The Confederation of Trade Unions issues recommendations on the wage developments, but these are not binding for the concrete bargaining that takes place at lower levels. Also, bilateral bargaining at the national level sets the statutory national minimum wage. In 2004 it was at 34 per cent of the average wage. Recalculated in PPP, this is at least 2.5 times smaller than the minimum wage in Portugal and over six times smaller than the minimum wage in Luxembourg. There is no obligatory wage indexation in Estonia.

The main level of collective wage negotiations is therefore the enterprise. In general, the firms of a given sector are quite diverse in terms of productivity, and employers are reluctant to delegate bargaining power to their 
sectoral organizations, which operate mostly as lobbies. Consequently, "sectoral" wage agreements are most common in sectors dominated by a single producer or an oligopoly (e.g. railways, energy supply etc.)

This low bargaining coverage is mostly related to low union presence, in particular in small and mediumsized firms in the private sector. Similarly to the majority of the former Soviet Republic's Central and Eastern European countries the average union membership in Estonia has significantly declined during independence. The union density (TUD) is estimated at 12.9 per cent, which is much lower than in Finland and Sweden and also lower compared to new member states of the EU (see Figure 4). Union coverage (CBC) in Estonia is 24 per cent.

In recent years Estonia has planned to encourage workers and employers to set the right framework for wage bargaining. Though the Estonian Government annually confirms the national minimum wage according to the minimum wage agreement between partners, the coverage with collective agreements at the sectoral level of the economy is relatively modest. Therefore, it is aimed to create a legal framework which promotes greater involvement in collective bargaining especially at sectoral level (Action Plan, 2005).

Figure 4: Trade union density and collective bargaining coverage

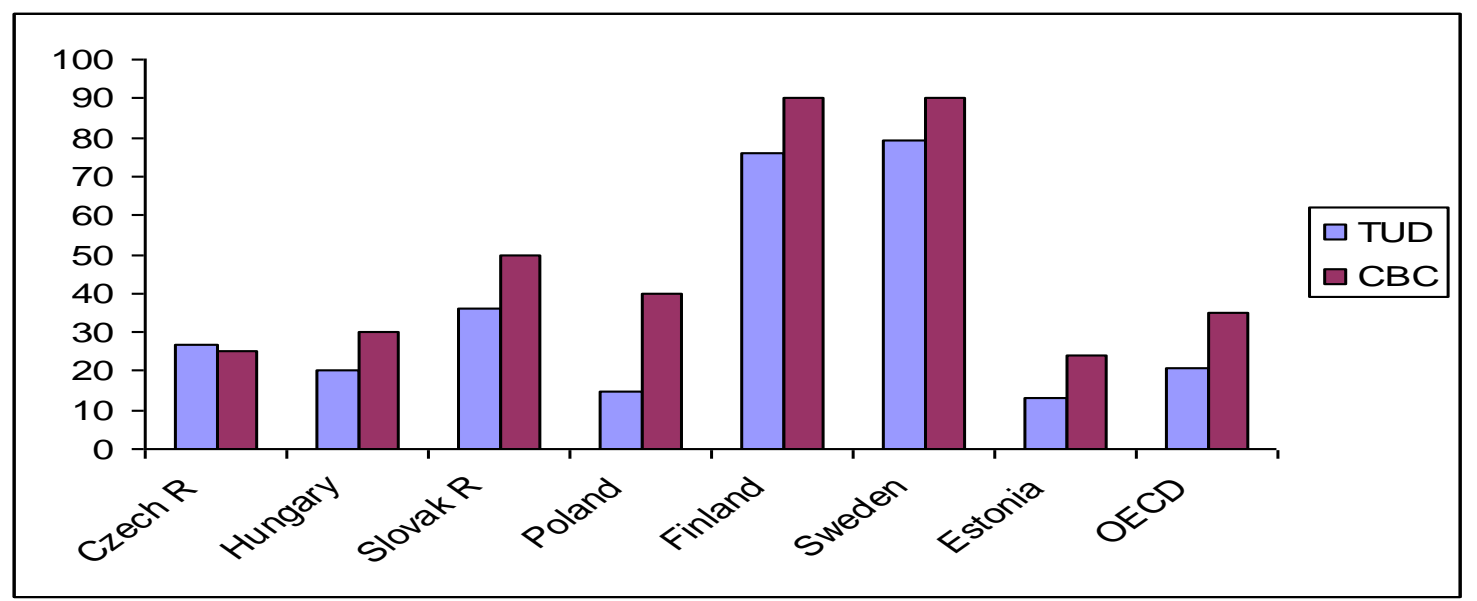

Source: ETU, 2002; ETU, 2003; OECD, 2004. (2000 for Finland, Sweden; 2001 for Czech Republic, Hungary, Poland; 2002 for Slovak Republic)

\section{Labor Market Policy Measures}

In 2005 the public labor market spending in Estonia was 12.86 million EUR. The share of active policy measures was 74 per cent of total measures and the share of passive labor market policy measures was 26 per cent of all expenditures. As it is known the unemployed persons need social protection to guarantee satisfaction of their primary needs. However, it should not reduce their eagerness to find employment.

Empirical evidence shows that an unemployment benefit scheme may help to create the mentality of dependant, so encouraging unemployment. Unemployment benefit can increase the duration of individual unemployment. According to Gangl, unemployment benefit can contribute to more productive matches on the labor market since this benefit works as a search subsidy so that jobseeker can choose a job offer that matches his/her profile better than an offer accepted because of financial need (Gangl, 2002). Given the above, the ratio of unemployment benefit to the future wages should be such that people will be motivated to find a job. To achieve this purpose deep analysis is required to find a well-grounded and flexible combination of active and passive labor market measures. 
In Estonia unemployment benefits are one of the lowest among the EU member states. Although the low level of unemployment benefits (63.9 EUR/month) was meant to provide a strong incentive for the unemployed to search for a new job within a short time span, in some regions of Estonia unemployment benefits and social maintenance are still considered to decrease the motivation to find a job. Even the low level of unemployment benefits may still cause some disincentives for job search because of local housing and heating subsidies linked to unemployment benefits and high transport costs (IMF, 2001).

In recent years the public expenditure on labor market policy in passive measures has diminished in Estonia. The main cause for the decrease of these expenditures is the fall in the unemployment rate and the decrease of the number of unemployed who received the benefit. Due to the change in the number of beneficiaries the expenditures to unemployment benefits fell by 29 per cent in 2005 in comparison with 2004.

There is no doubt that effective active labour market policies are a significant part of a strategy to combat high unemployment. Nevertheless, they are not a magic bullet on their own to solve the unemployment problem, as Calmfors (1995) warned. The experience of OECD countries shows that there is no clear relationship between the average ratio of active labour market policy spending to GDP and the average rate of unemployment (for the same year) over time (OECD, 2001). Many other researchers have also reached the conclusion that the role of active labor market policies in rehabilitating unemployed persons back to employment is relatively small (Heckmann, Lalonde, and Smith, 1999; Martin and Crubb, 2001). Also in East Germany active labor market programs did not have significant positive effects on employment in 1990-1998 (Bergemann et al, 2000).

At the same time, it has been noted in some transition countries that active labor market policies considerably help unemployed people to return to employment (Kotzeva, 2001). Therefore it would be inconsiderate to draw pessimistic conclusions about the role of active labor market policies in the fight against high and persisting unemployment. Finding solutions to the above-mentioned problems requires further analysis of the results of implementing active measures to combine them with passive measures. As it is argued the impact of a relatively generous benefit system might be offset by suitable active policy measures that make the unemployed more willing to accept jobs or by making them more attractive to perspective employers (Martin and Crubb, 2001).

The design of active labour market policies depends on the main causes of unemployment persistence. Each cause needs a different design of these policies. For example, a temporary work experience program can be used in the interest of retaining skills and qualifications. For long-term unemployed training programs offer better possibilities. And if the reason for long-term unemployment is de-motivation, job-searchers programs may be most suitable (Calmfors, 1994).

As the causes of unemployment may vary between EU member states there are no uniform guidelines on the design of active labour market policies in different countries. However, in order to enhance the efficiency of using different policies countries should learn from each other's experiences. So there is a need to expand the quantity and quality of evaluations of active labour market policies across EU countries.

EU countries have already from the early 1990s tried to identify the role of active measures in the fight against unemployment. In 1992 OECD Ministers gave the Organisation the mandate to analyze the causes and consequences of unemployment and propose effective measures to deal with the problem. However, though politicians promote it widely, the relative growth of active measures has still been quite modest. In 1998 they accounted in OECD countries for approximately the same proportion of total labor market expenditure as in 1990. As regards expenditures needed for implementing active measures per unemployed person against GDP, then these were even smaller in 1998 than in 1990. Up to recent years the tendency of preferring passive measures might be encountered also in Estonia (Paas and Philips, 2002).

In general, in Estonia active labour market policies have a modest role which is less important than in the EU. On average, EU countries spend about 40 per cent of public labour market spending (or about 1.2 per cent of GDP) on active measures. Denmark has the biggest share of public expenditure on labor market policy in active measures in Denmark (1.516 per cent of GDP in 2003 and 1.523 per cent in 2004). In EU-15 the respective share 
has diminished somewhat - from 0.712 per cent of GDP in 2003 to 0.643 per cent in 2004. The opposite tendency is true about the share of labor market policy expenditure in passive measures - it increased from 1.446 per cent of GDP to 1.462 per cent in 2004.

In Estonia the absolute amount of public labour market spending is quite low - 0.12 per cent of GDP in 2005. In EU the respective figure was 2.48 percent of GDP in 2001. The share of active labor market measures from GDP in Estonia was 0.08 per cent in 2004 and 0.09 per cent in 2005. The share of passive labor market measures from GDP was 0.03 per cent in 2005.

The most important active labour market policies in Estonia are a labor market training program and a cash allowance for enterprise start-ups. It has to be stressed that the number of people participating in training programs organized by labor services has been relatively modest in comparison with the total number of unemployed. In 2004 on average only 9.2 per cent of the registered job-seekers participated in the public training programs. In 2005 the expenditure on public training programs increased by 45 per cent. The support of European Social Fund has plyed a significant role in this increase. Nevertheless, the current situation is clearly not satisfactory. Active labor market measures should be made available for a greater share of the unemployed. Receiving benefits should be made conditional on active job search in order to motivate people to take up employment.

New acts in 2000 widened the access to labor market programs by redefining the unemployed and introduced a new service - vocational counseling. In 2005 the total number of unemployed persons who participated in vocational counseling increased by 12 per cent compared with 2004. The target group for vocational guidance most needing the service includes the young unemployed and the long-term unemployed due to the lack (or loss) of vocational, educational and occupational training, professional skills and job searching skills; and the unemployed in need of retraining.

Researches conducted in Estonia indicate that active labor market measures should be used primarily to support young people, people with primary and basic education and people in pre-pension age with high educational attainment (Paas and Philips, 2002). The main target group for measures like further training and retraining should be the persons with high educational attainment and even older workers who have the potential for adapting relatively quickly to new tasks as they have a large stock of accumulated human capital and are better motivated. Other problem groups (unskilled, low-educated) could be targeted for subsidized employment schemes.

In coming years Estonia should focus on combined usage of active labor market measures. Special attention has to be paid to the provision of labor market training for a larger number of unemployed, which could help to reduce structural unemployment. Some problems related with active labor market policies in Estonia are the following: (1) the ignorance of the government about the future labor demand; (2) possible crowding out of employed people by unemployed people participating in programs; (3) the fact that active labor market programs reduce unemployment only temporarily and (4) rent-seeking behavior of the suppliers of certain programs and the ensuing inconsideration of national economic needs (Freytag, 2002).

Improving the use of active labor market policy measures requires evaluating the effects of active labor market policies. Evaluations of developed countries' experiences with active labor market policies are well summarized by studies of OECD (Martin, 1998). At the same time the evidence on transition economies is quite scarce.

Evaluating the effects of active labor market policies can be based on micro- and macroeconomic approaches to active labor market policies. As Richardson argues, there are a large number of micro-level studies of active labor market policies (see OECD, 1993 for a survey). But there have been few attempts to model active labor market policies in a macroeconomic context. Most of the attempts at macroeconomic modeling have concluded that the effect of policy is ambiguous (Jackman, 1994).

For microeconomic evaluations different outcome measures can be used. In the United States the microeconomic evaluations mostly focus on the earning effects after training programs participation (Riddell, 1991). 
In Germany these evaluations focus mostly on the training effect on the employment situation. As Schmidt (1999) notes, some problems arise with the choice of an outcome measure. For instance, improvement in the employment situation may be measured in several ways, for example by a distinction between employment or unemployment or by the duration of unemployment (or employment) after the intervention has taken place (Hujer, Maurer and Wellner, 1999). Microeconometric evaluations of vocational training and job creation schemes in Germany (Hujer and Caliendo, 2000) allow no definite conclusions, as there is significant variation regarding the estimated effects of these measures. In 2003 the first attempt to evaluate active labor market programs using micro-level analysis was made in Estonia. (Leetmaa and Võrk, 2003). The conclusion was that programs carried out in 2000 had a positive impact on later employment probability. According to Hujer and Caliendo (2000) in Germany the major problem of evaluation seems to be the fact that the available data were rather crude. There is no doubt that the scarcity of statistical data is a problem also for Estonia.

\section{Conclusions}

- $\quad$ Recent developments of the Estonian labor market have been positive: the employment rate has increased and unemployment rate has fallen. If the women employment rate is by 6 percentage points higher than that of EU-15, the employment rate of men is lower than in Estonia only in Lithuania and in Poland. It can be concluded that in the near future the main attention has to be paid to raising the men`s employment rate.

- $\quad$ Our research has proved that the Estonian labor market is quite flexible: it is characterized by a weak role of trade unions and modest regulation of labor market by the government. Unemployment benefits and active labor market policy play a dual role. On the one hand they insure against labor market risk providing income and employment security. On the other hand they influence the capacity of labor market to adapt to changing economic conditions. We have reached the conclusion that in spite of this labor market flexibility and transparency in Estonia have to be increased further.

\section{Acknowledgements}

This research was conducted with support from the Estonian Science Foundation (Research Project 6168).

\section{References}

1. Action Plan for Growth and Jobs 2005-2007 (2005), The implementation of the Lisbon Strategy, Tallinn.

2. Bergemann, A., Fitzenberger, B., Schults, B., and Speckesser, S. (2000), Multiple Active Labour Market Policy Participation in East Germany - An Assessment of Outcomes, Konjunkturpolitik,Beiheft No 51, pp 195-243.

3. Botero, J.C., Djankov, S., La Porta, R., Lopez-de-Silanes, F., Shleifer, A. (2004), The Regulation of Labor, The Quarterly Journal of Economics, November 2004.

4. Calmfors, L. (1995), What Can We Expect from Active Labour Market Policy? Konjunkturpolitik, 43, pp $1-30$.

5. Cases, S., Nesperova, A. (2001), Towards excessive job insecurity in transition economies? ILO Employment paper No. 23. http:www.ilo.org/public/English/employment/strat/download/ep23.pdf.

6. Clar, M., Dreger, C., Ramos, R. (2007), Wage Flexibility and Labour Market Institutions: A MetaAnalysis, Forschungsinstitut zur Zukunft der Arbeit Institute for the Study of Labor, January 2007.

7. Faggio, G., Koenings, J. (1999), Gross Job Flows and Firm Growth in Transition Countries: Evidence Using Firm Level Data on Five Countries. In: CEPR Discussion Paper, October 1999, No. 2261.

8. Freytag, A. (2002), Estonian Labour Market and EMU Membership - Challenges and Policy Options. Working Papers of Eesti Pank, No 11, Tallinn.

9. Fainštein, G., Kerem, K., and Lubenets, N. (2006,. Wage Determination in Estonia, The Business Review, vol. 5, nr. 1. New York.

10. Gangl, M. (2002), Unemployment Benefits as a Search Subsidy: New Evidence on Duration and Wage Effects of Unemployment Insurance, WZB Discussion Paper FSI 208, Berlin.

11. Eamets, R. (2001), Reallocation of Labour during Transition Disequilibrium and Policy Issues. The Case of Estonia. Tartu. 
12. Eamets, R., Masso, J. (2003), Labour Market Flexibility and Employment Protection Regulation in the Baltic States. Working Papers in Economics (TTUWPE No 03/91-03/103), Tallinn.

13. 13.Europe in Figures - Eurostat yearbook 2006-07.

14. Haltiwanger, J., Vodopivec, M. (1999), Gross Worker and Job Flows in a Transition Economy: an Analysis of Estonia. Policy Research Working Paper, No. 2082, The World Bank.

15. Heckman, J. J., Lalonde, R. J., Smith, J. A. (1999), The Economics and Econometrics of Active Labor Market Programs. Handbook of Labor Economics. Vol. 3A, Amsterdam: North-Holland, Elsevier.

16. Hujer, R., K. Maurer, and M. Wellner. (1999), The Effects of Public Sector Sponsored Training on Unemployment Duration in West Germany - A Discrete Hazard Rate Model Based on a Matched Sample, Ifo-Studien, 3/1999, 45 Jhg., 371-410.

17. Hujer, R., M. Caliendo. (2000), Evaluation of Active Labour Market Policy: Methodological Concepts and Empirical Estimates, Discussion Paper No. 236, December 2000.

18. International Monetary Fund. (2001), "Labour Markets in Hard-Peg Accession Countries: The Baltics and Bulgaria". IMF Country Report No 01/100, July, Washington DC, quoted as IMF.

19. Jackman, R. (1994), What Can Active Labour Market Policy Do? Swedish Economic Policy Review, 1 (12), pp 221-257.

20. Kotzeva, M. (2001), Evaluation of Active Labour Market Programmes in Bulgaria. Paper presented in the EALE Conference 2001, Jyväskylä, Finland.

21. Leetmaa, R., Võrk, A. (2004), Evaluation of Active Labour Market Programmes in Estonia. Working Papers of Eesti Pank, Tallinn.

22. Martin, J. P. (1998), What works among active labor market policies: evidence from OECD countries` experiences. Labor Market and Social Policy Occasional Papers No. 35. Paris.

23. Martin, J. P., Grubb, D. (2001), What works and for whom: A Review of OECD Countries`Experiences with Active Labour Market Policies. Paper presented at the conference "What are the effects of active labour market policy?” IFAU - Office of Labour Market Policy Evaluation, Stockholm, October 8, 2001.

24. OECD (2004), OECD Employment Outlook, Paris: Organisation for Economic Cooperation and Development.

25. OECD (2001), OECD Employment Outlook, Paris: Organisation for Economic Cooperation and Development.

26. OECD (1993), OECD Employment Outlook, Paris: Organisation for Economic Cooperation and Development.

27. Paas, T. et al (2002), Labour Flexibility and Migration in the EU Eastward Enlargement Context: the Case of the Baltic Countries, Mimeo, University of Tartu.

28. Paas, T, Philips, K. (2002), Long-term Unemployment in Estonia: To support Passive Adaptation or Active Development? In: Effect of Accession to the European Union on the Economic Policy of Estonia, Proceedings of the X Scientific and Educational Conference. Berlin, Tallinn, 2002.

29. Riddell, C. (1991), Evaluation of Manpower and Training Programmes: The North American Experience, in Evaluating Labour Market and Social Programmes, The State of a Complex Art, ed. by OECD, pp. 4372. OECD.

30. Rõõm, M. (2002), Unemployment and Labour Mobility in Estonia: Analysis Using Duration Models, Working Papers of Eesti Pank, No 7, Tallinn.

31. Siebert, W. S. (2006), Labour Market Regulation in the EU-15: Causes and Consequences - A Survey, Forschungsinstitut zur Zukunft der Arbeit Institute for the Study of Labor, November 2006.

32. Schmidt, C. (1999), Knowing What Works - The Case for Rigorous Program Evaluation, Discussion Paper No. 77, IZA.

33. Toomet, O. (2001), The Immediate Returns to Internal Migration. The Estonian Case. Eesti Vabariigi majanduspoliitika harmoniseerimine ja Euroopa Liit, Tallinn.

34. Toomet, O. (2000), Tööjõu liikuvus Eestis: empiiriline uuring. Eesti Vabariigi majanduspoliitika tulemuslikkus ja Euroopa Liit, Tallinn.

35. Venesaar, U., Marksoo, Ü. and Maldre, M. (2001), Outflow from Employment and Resulting Social Exclusion of the Vulnerable Groups in Estonia", in: Ülo Ennuste and Lisa Wilder (Eds.), Factors of Convergence. Tallinn Technical University, Tallinn. 